\title{
Dry sliding wear of Ni alloyed austempered ductile iron
}

\author{
*E. Akbarzadeh Chiniforush, M. A. Rahimi, and S. Yazdani \\ Faculty of Materials Engineering, Sahand University of Technology, Tabriz, Iran
}

\begin{abstract}
Measurements of dry sliding wear are presented for ductile irons with composition Fe-3.56C-2.67Si$0.25 \mathrm{Mo}-0.5 \mathrm{Cu}$ and $\mathrm{Ni}$ contents of 0.8 and $1.5 \mathrm{in}$ wt.\% with applied loads of 50,100 and $150 \mathrm{~N}$ for austempering temperatures of 270,320 , and $370{ }^{\circ} \mathrm{C}$ after austenitizing at $870{ }^{\circ} \mathrm{C}$ for $120 \mathrm{~min}$. The mechanical property measurements show that the grades of the ASTM 897M: 1990 Standard can be satisfied for the selected austempering conditions. The results show that wear resistance is independent of austempering temperature with an applied load of $50 \mathrm{~N}$, but there is a strong dependence at higher austempering temperatures with applied loads of 100 and $150 \mathrm{~N}$. Observations indicate that wear is due to subsurface fatigue with cracks nucleated at deformed graphite nodules.
\end{abstract}

Key words: austempered ductile iron; wear; austenite; ausferrite; nickel

CLC numbers: TG143.5 Document code: A Article ID: 1672-6421(2016)05-361-07

$\mathrm{U}$ ntil the beginning of the 20th century, the most important property of a casting was its shape, while the mechanical or physical properties were in the second order of importance. A significant development in the field was the discovery of the effect of magnesium on grey cast iron in 1943. The result was the generation of a new cast iron family (ductile iron) with higher tensile strength and ductility compared to that of grey cast iron. A significant advance in the cast iron technology and an equally important development is the austempering of ductile iron. The remarkable combination of properties attainable in austempered ductile iron (ADI) has caused this material to emerge as a new class of ductile iron. The outstanding mechanical properties of ADI are due to the presence and continuity of the FCC austenite matrix. Compared to conventional grades of ductile iron, ADI exhibits more than twice the strength for a given level of ductility. ADI is lighter, stronger and more wear-resistant than steel. Consequently, it is replacing steel forgings, weldments and castings as a weight-saving material

\section{*E. Akbarzadeh Chiniforush}

Final year post graduate student in the field of Materials Science and Engineering in Sahand University of Technology, Tabriz, Iran. She is doing her MSc. thesis under the supervision of Professor Sasan Yazdani. She is working in the fields of advanced nanostructured steels and austempered ductile iron (ADI), in Professor Yazdani's research group.

E-mail: E_akbarzadeh@sut.ac.ir, e.akbarzade@gmail.com (E. Akbarzadeh Chiniforush), Yazdani@sut.ac.ir (S. Yazdani )

Received: 2016-07-11; Accepted: 2016-07-30 in many applications. The wear behaviour of ADI has been studied by several researchers ${ }^{[1-6]}$, but most have reported differing results, as wear behaviour of ADI depends on many factors such as alloying elements content, heat treatment variables, test mechanism and the applied load. In this paper, the studies of the influence of $\mathrm{Ni}$ on dry sliding wear behaviour and the relationship between them under different austempering heat treatment conditions are presented.

\section{Austempering process in ductile iron}

Figure 1 illustrates a typical austempering heat treatment cycle. It consists of heating to and holding at an austenitizing temperature in the range $850-950{ }^{\circ} \mathrm{C}$ (A-B) for a period of time (B-C) to change the as-cast matrix structure into austenite. The next step is to cool rapidly to the austempering temperature (C-D) in the range $260-450{ }^{\circ} \mathrm{C}$ and to hold at this temperature (D-E) to achieve the isothermal transformation of austenite to ausferrite. The iron is then cooled to room temperature (E-F). Austempering temperature is selected to achieve the desired grade of ADI. Austempering time is selected to achieve the optimum mechanical properties. The goal of the austempering process is obtaining reacted high carbon austenite and finely dispersed acicular ferrite. 


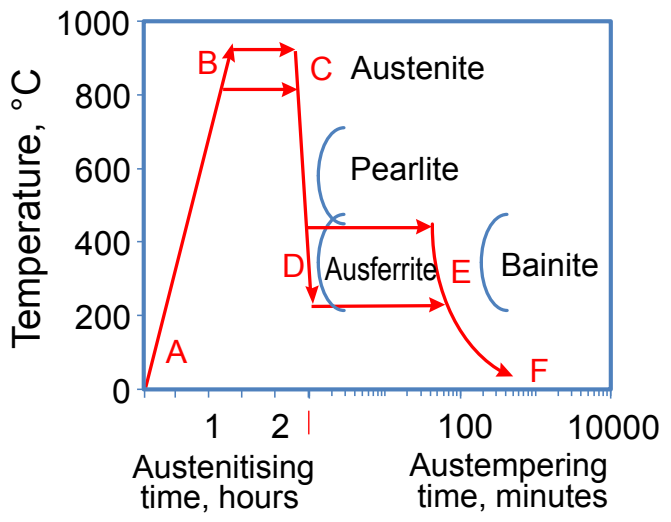

Fig. 1: Typical austempering heat treatment cycle in ductile iron

\section{Austempering reaction}

The austempering reaction in ductile irons is a two stage reaction that differs considerably from the single stage bainite reaction in steels. The description of austempered ductile iron is preferred to bainitic ductile iron to emphasize the differences in the two reactions ${ }^{[7]}$. Figure 2 shows the differences in the two reactions.

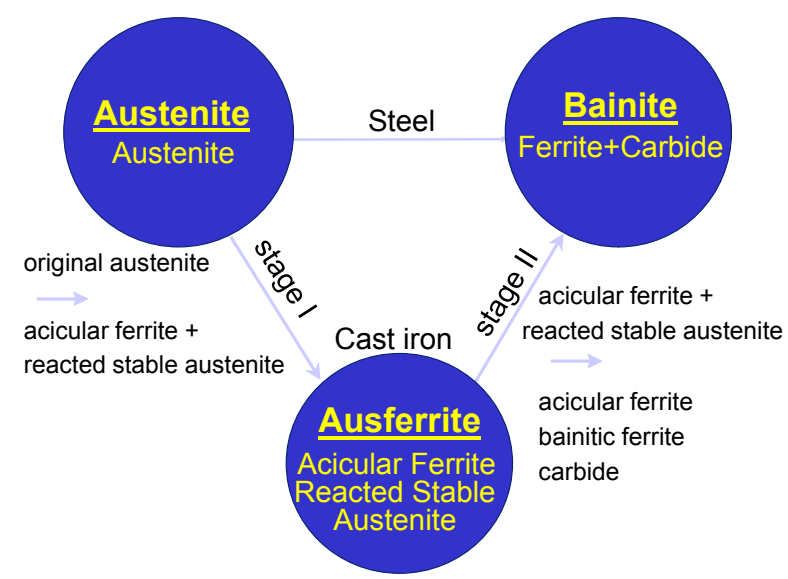

Fig. 2: Differences in austempering reaction in steel and cast iron

In steel, austempering is a single step process in which austenite transforms directly to bainite whereas in ductile iron it is a two step process. In the first step, austenite $(\gamma)$ transforms to acicular ferrite $(\alpha)$ (or ferrite and carbide) and high carbon austenite $\left(\gamma_{\mathrm{H}}\right)$. In the second step, when the casting is austempered longer than required, the matrix decomposes to form more stable ferrite and carbide.

Stage I:

$$
\gamma \rightarrow \gamma_{\mathrm{H}}+\alpha \text { or }(\alpha+\text { carbide })
$$

Stage II:

$$
\gamma_{\mathrm{H}} \rightarrow \alpha+\text { carbide }
$$

The high ductility associated with high strength is not derived from a bainite microstructure but from a microstructure of acicular ferrite and high carbon austenite that has been termed officially by ASTM ${ }^{[8]}$ as ausferrite implying that it is largely a mixture of austenite and ferrite.

The austempering reaction starts with the formation and growth of acicular ferrite on the austenite boundaries and graphite matrix interface. The high silicon content of ductile iron suppresses the formation of carbides normally associated with bainitic reactions, allowing carbon rejected by the growing acicular ferrite to enrich the surrounding austenite. This austenite is enriched in carbon sufficiently to become thermally stable to well below room temperature. Austenite carbon contents in the range $1.8 \%-2.1 \%$ result in an austenite, which is stable to transformation to martensite upon cooling after austempering. The amount of high carbon austenite increases during the stage I reaction reaching a plateau corresponding to the end of the stage I reaction, time $t_{1}$. Then the amount of high carbon austenite begins to fall during the stage II reaction, time $t_{2}$ when the austenite decomposes to ferrite and carbide. Insufficient holding time at the austempering temperature leaves un-reacted austenite in the structure at intercellular boundaries. This low carbon austenite is thermally unstable and transforms to martensite upon cooling to room temperature. These areas are termed unreacted austenite volumes, UAV. With higher amounts of UAV, these areas form a continuous or semi-continuous easy path for crack propagation and significantly reduce the ductility of austempered ductile iron. The time interval between the end of the stage I reaction, $t_{1}$, and the beginning of the stage II reaction, $t_{2}$, is the heat treatment processing window within which the ausferrite structure forms and optimum mechanical properties are obtained. Excessive holding at the austempering temperature is undesirable because it results in decomposition of the reacted stable austenite to form more thermodynamically stable ferrite and carbide. During the time interval between the end of the stage I reaction, $t_{1}$, and the beginning of the stage II reaction, $t_{2}$, the microstructure consists of acicular ferrite plus reacted high carbon austenite at high austempering temperatures and ferrite (containing carbides) plus reacted high carbon austenite at low austempering temperatures ${ }^{[9-13]}$

\section{Experimental procedures}

\subsection{Alloy and heat treatment process}

The chemical composition of ductile irons used in the present research is given in Table 1. The alloys of both groups were produced by the sandwich spheroidization technique and cast into the 1-inch thick standard Y-blocks. Samples of wear tests were machined off from the bottom section of the blocks in order to avoid the defects present in the top region and minimize differences in the size and distribution of graphite nodules. Test specimens were austenitized at $870{ }^{\circ} \mathrm{C}$ for 90 minutes based on preliminary measurements, which showed that the development of the austenite phase was completed, and excessive austenite grain growth was avoided. Austempering was conducted at 270, 320 and $370{ }^{\circ} \mathrm{C}$ for times between 5 minutes and 24 hours after austenitizing. The specimens were air cooled after austempering. 
Table 1: Composition of ductile irons used (wt.\%)

$\begin{array}{ccccccccc} & \text { Mn } & \text { Ni } & \text { Cu } & \text { Mo } & \text { P } & \text { S } & \text { Si } & \text { C } \\ \text { Group I } & 0.2 & 0.8 & 0.5 & 0.25 & 0.01 & 0.015 & 2.67 & 3.56 \\ \text { Group II } & 0.21 & 1.5 & 0.54 & 0.23 & 0.014 & 0.013 & 2.58 & 3.6\end{array}$

\subsection{Microstructural evaluations}

Samples for metallographic observation were ground and polished following the standard procedures after heat treatment. $2 \%$ nital etching solution and subsequent etching in sodium metabisulfite $20 \%$ solution were used to reveal the microstructure. Microstructural evaluations were conducted on Olympus PMG3 ${ }^{\mathrm{TM}}$ optical microscope. Cam Scan MV-2300 ${ }^{\mathrm{TM}}$ scanning electron microscope (SEM) operating at $30 \mathrm{kV}$ was also used to study the microstructure.

\subsection{Hardness measurements}

Rockwell hardness testing machine (HRC) was used to measure the hardness. A total number of six hardness measurements at different locations were taken. The average value was calculated and used for the analysis. The hardness of transverse sections was measured for all specimens using a microhardness tester with an applied load of $50 \mathrm{~g}$.

\subsection{Wear tests}

Dry sliding wear tests were carried out according to ASTM G99 standard using a block-on-ring wear test machine specially built for laboratory use on samples with dimensions $10 \mathrm{~mm} \times 10$ $\mathrm{mm} \times 20 \mathrm{~mm}$. Specimens were tested under dry atmospheric condition against a surface hardened tool steel ring at a speed of $3.7 \mathrm{~m} \cdot \mathrm{s}^{-1}$ with normal loads of 50,100 and $150 \mathrm{~N}$. The weight loss of the specimens was taken at intervals of 10 minutes, with a precision of $\pm 1 \mathrm{mg}$. Morphologies of the worn surface were examined by optical and scanning electron microscopes.

\section{Results and discussion}

\subsection{Characteristics of as-cast iron}

The as-cast structure showed a typical bull's eye structure with ferrite surrounding the graphite nodules in a pearlitic matrix with a little intercellular carbide. For consistency in nodule count, all samples in this study were prepared from the bottom part of blocks. The nodule count in this region was $110-130$ per $\mathrm{mm}^{2}$ with a nodularity of over $90 \%$.

\subsection{Hardness}

Figure 3 shows the hardness values for different austempering time and temperatures. The progress of the stage I reaction is accompanied by an increase in volume fraction of high carbon austenite and a decrease in the hardness. The hardness again increases during the stage II reaction. From the figure, it can be seen that the hardness values of both groups are similar which suggest that Ni does not have any significant effect on this property.

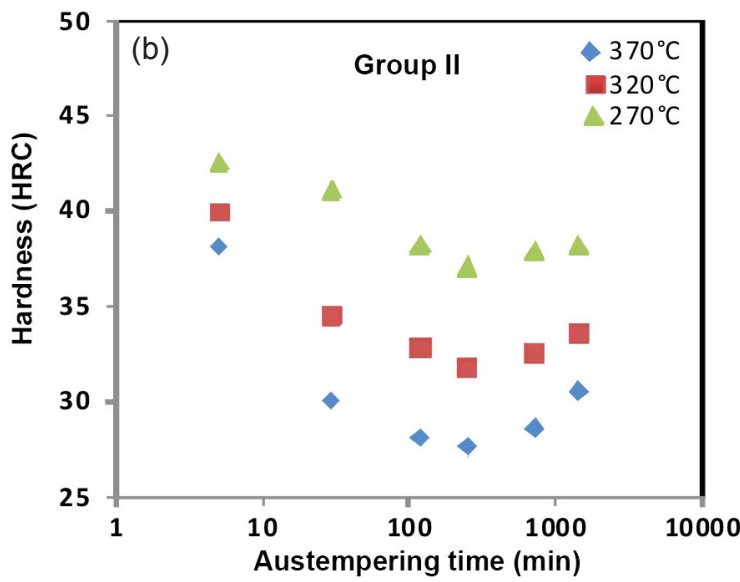

Fig. 3: Variation of hardness with austempering time for different austempering temperatures: (a) Group I, (b) Group II

\subsection{Wear behavior}

The variation in weight loss with sliding distance under different applied loads for austempered specimens is shown in Fig. 4. The effect of increasing applied load is to increase the weight loss at a given distance travelled. The low values of wear properties at short austempering times are attributed to the brittleness induced by large amounts of martensite, which was formed from the unreacted low-carbon austenite after cooling to room temperature. As a result, the minimum requirements of ASTM standard can not be satisfied and high rates of wear would be observed. In other words, the large martensite contents and resulting brittle fracture during wear are responsible for low values of this property at a short austempering time. Further increase of austempering time improves the mechanical properties of ADI, including wear resistance ${ }^{[14]}$. All the samples that were austempered within the heat treatment processing window show a similar wear behaviour. 

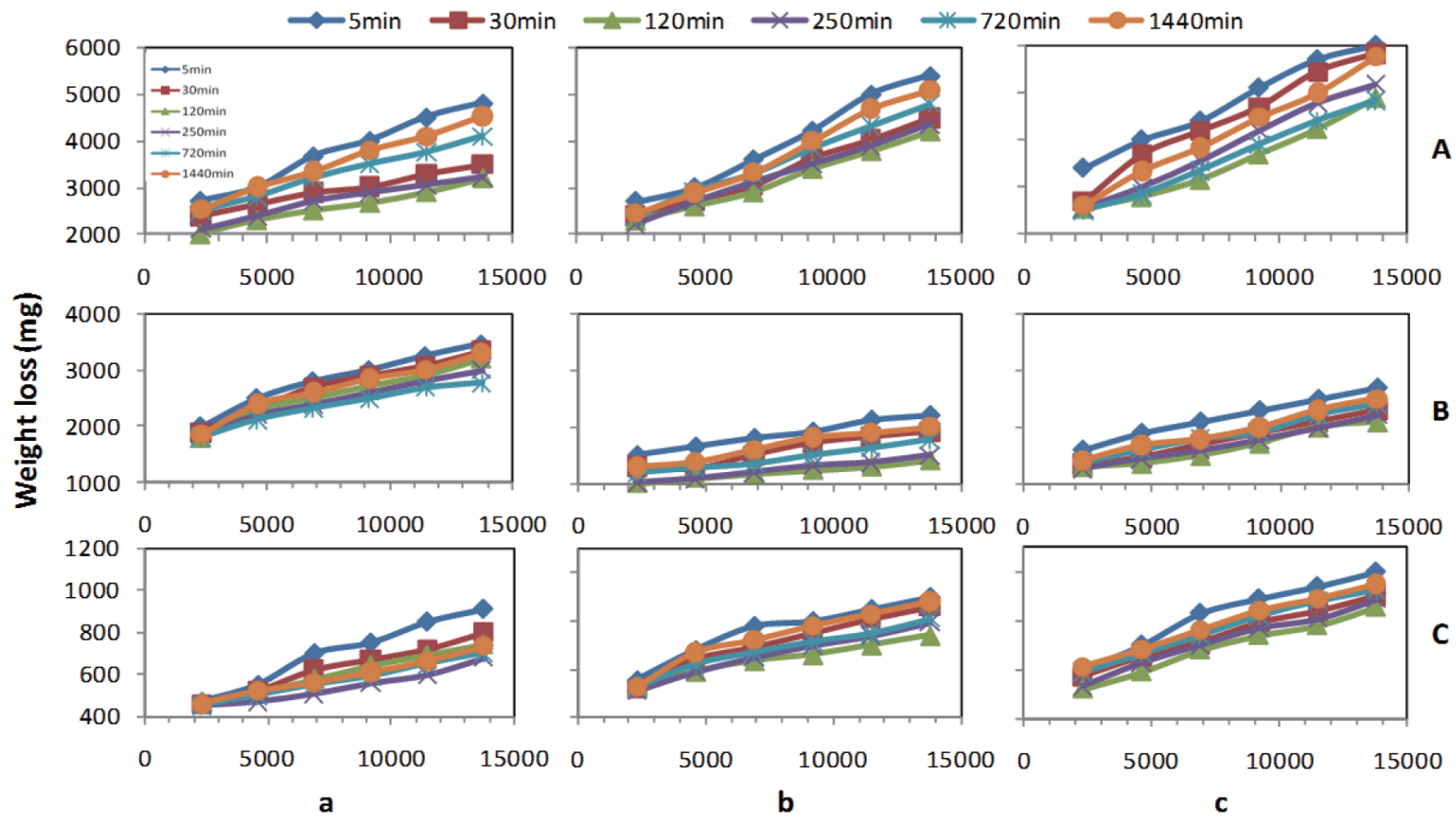

Sliding distance $(m)$

Fig. 4: Variation of weight loss with sliding distance for different applied loads with various austempering heat treatments (Group II): (a) $270^{\circ} \mathrm{C}$, (b) $320^{\circ} \mathrm{C}$, (c) $370^{\circ} \mathrm{C}$; (A) F=150 N, (B) F=100 N, (C) F=50 N

Wear can be discussed in terms of applied loads. From Fig. 4, it is evident that the lower applied load of $50 \mathrm{~N}$ causes what can be considered as 'mild wear' for all austempering heat treatments with very little differences among them. The wear behaviour for this load shows a complete independence on austempering temperature. Figure 5(a) shows the surface topography of the worn ADI under a load of $50 \mathrm{~N}$, which consists of shallow wear scars. This behaviour is the result of smooth graphite film, which was formed on the sliding surface due to the presence of graphite nodules in the microstructure ${ }^{[8]}$. The film effectively suppresses the adhesive bonding at the sliding interface, which is evident in Fig. 5(a). The increase of load to $100 \mathrm{~N}$ enhances the roughness of the surface and deeper wear scars could be seen as shown in Fig. 5(b). With the increase of load to $100 \mathrm{~N}$, weight loss of specimens austempered at $270{ }^{\circ} \mathrm{C}$ increases, in spite of the high strength of samples. Results indicate that under this applied load wear resistance of samples austempered at 320 ${ }^{\circ} \mathrm{C}$ is better than that of samples austempered at 270 or $370{ }^{\circ} \mathrm{C}$. But with further increase of load up to $150 \mathrm{~N}$, the austempered samples of $370{ }^{\circ} \mathrm{C}$ display a better wear resistance compared to
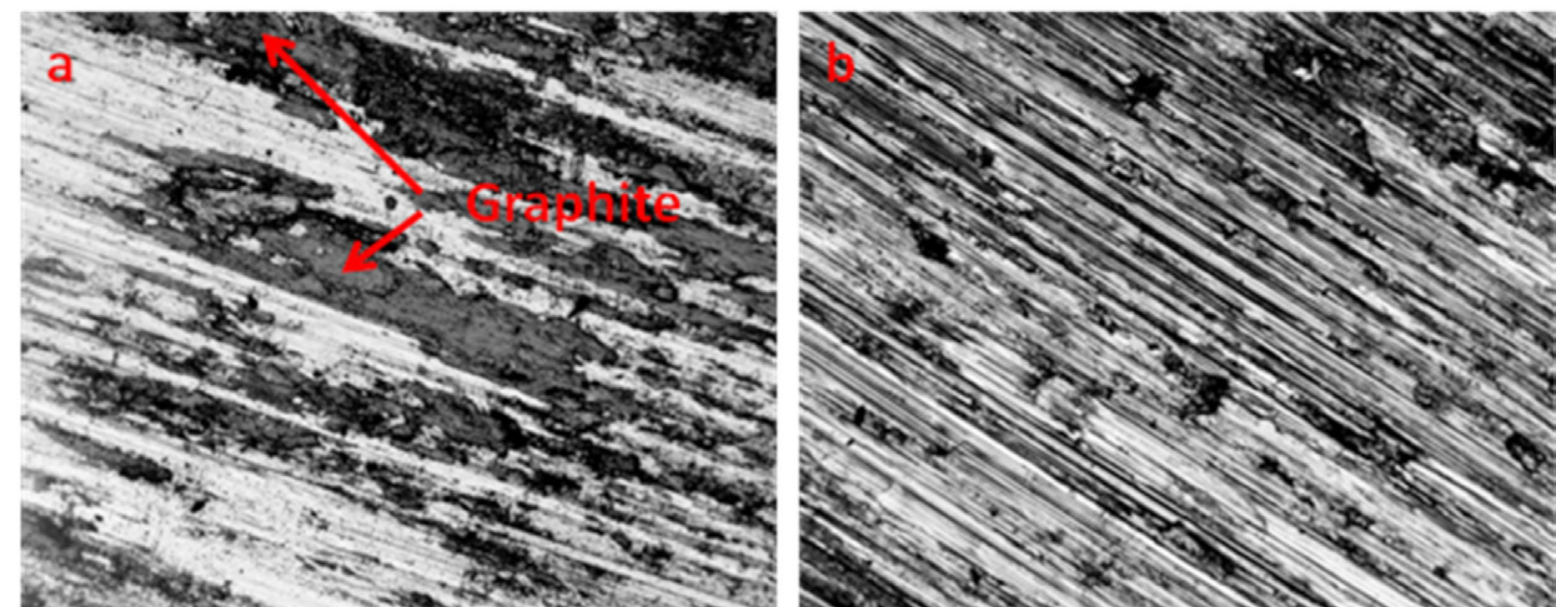

Fig. 5: Appearance of worn surface: (a) samples austempered at $320^{\circ} \mathrm{C}$ for 120 minutes (Group II), at an applied load of $50 \mathrm{~N}$ (Dark regions are torn films of graphite), (b) samples austempered at $370{ }^{\circ} \mathrm{C}$ for 30 minutes (Group II), at an applied load of $100 \mathrm{~N}$ 
the samples of other austempering temperatures.

Figure 6 shows the variation of hardness on the transverse section of samples with distance from the surface for different heat treated specimens after wear testing. Very high increases in superficial hardness can be observed, but this variation is within a very narrow layer. For samples austempered at $270{ }^{\circ} \mathrm{C}$, the increase in hardness is relatively small. This behaviour is associated with the lower volume fraction of austenite, which is available. Under the load of $100 \mathrm{~N}$, work hardening and hardness increase for austempered samples of 320 and $370{ }^{\circ} \mathrm{C}$ is approximately the same. When load increases to $150 \mathrm{~N}$, wear behaviour changes and test samples of $370{ }^{\circ} \mathrm{C}$ show a better wear resistance (Fig. 4). From Fig. 6, it is clear that under a high load of $150 \mathrm{~N}$ the interfacial hardness increase is higher in samples austempered at $370{ }^{\circ} \mathrm{C}$. This behaviour is attributed to the higher work hardening of samples with higher volume fractions of high carbon austenite under a high load.
ADI microstructure consists of metastable austenite that transforms to martensite in the deformed regions during wear ${ }^{[7,16-17]}$. Transformation of austenite to martensite depends on its carbon content. The austenite transformation with lower carbon contents, e.g. the samples austempered at $370{ }^{\circ} \mathrm{C}$, is more likely than that of the samples austempered at lower temperatures, since the carbon content of austenite increases by decreasing the austempering temperature. Austenite transforms to martensite by the TRIP (transformation induced plasticity) mechanism. This martensite which is formed by deformation is carbide free and nucleates at austenite twins or twin intersections ${ }^{[15]}$. Figure 7 shows that specimens of group II under the load of $150 \mathrm{~N}$ display a better wear resistance. As mentioned earlier, by increasing the Ni content, the amount of high carbon austenite increases, so that under a load of 150 $\mathrm{N}$, work hardening occurs more than that of group I. Figure 8 shows the microstructure of th plastically deformed region

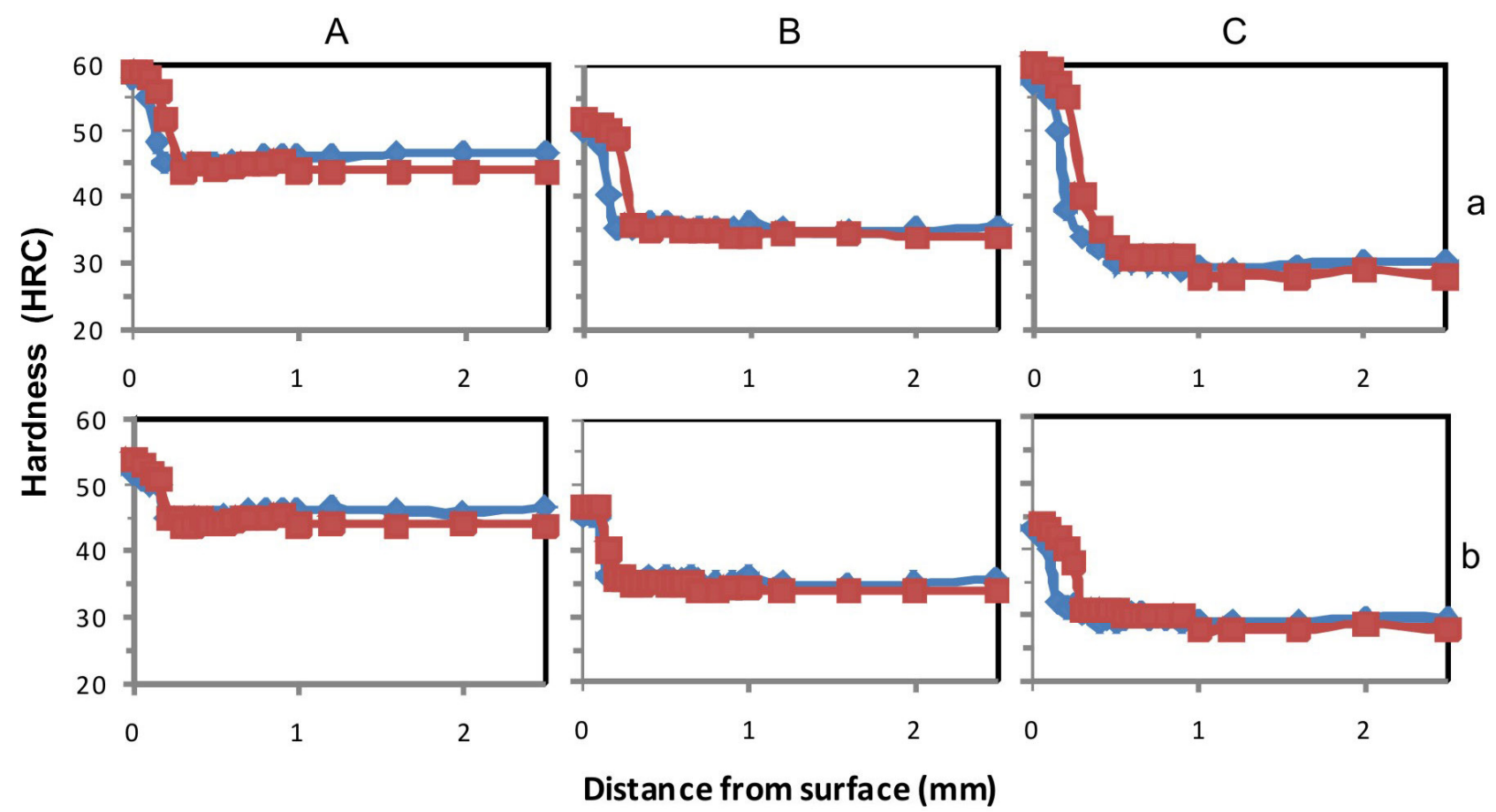

Fig. 6: Variation of hardness with distance from the surface after wear test for one hour: (a) $F=100 \mathrm{~N}$, (b) $F=150 \mathrm{~N}$; austempering temperature: (A) $270{ }^{\circ} \mathrm{C},(B) 320^{\circ} \mathrm{C}$, (C) $370^{\circ} \mathrm{C}$; austempering time: 120 minutes
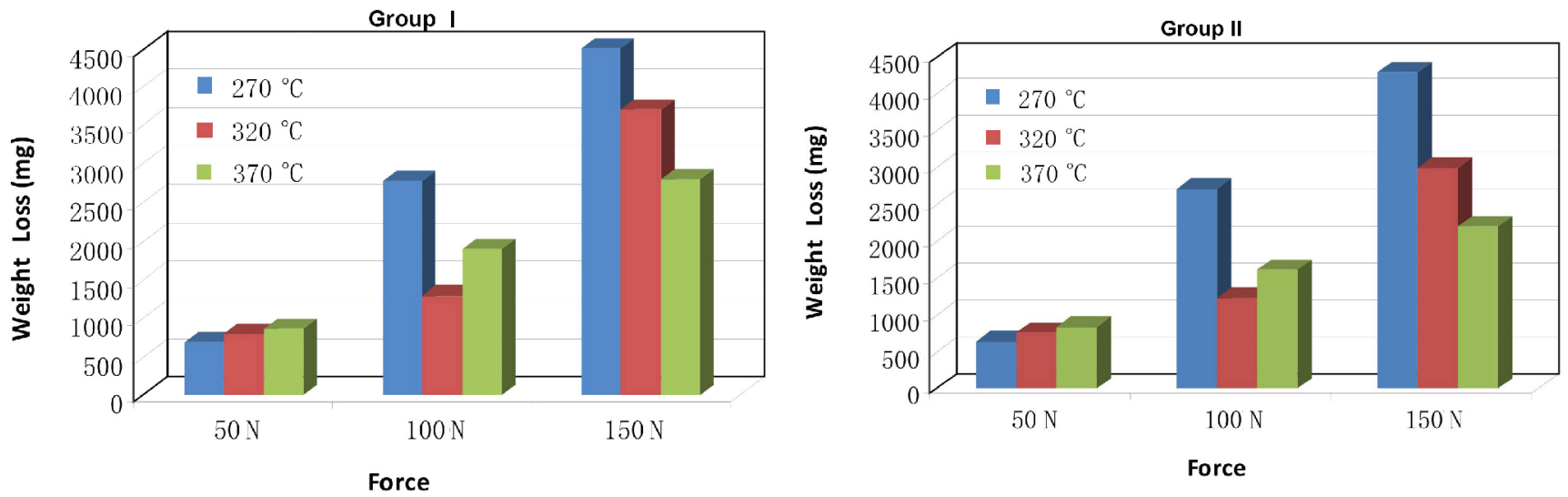

Fig. 7: Variation of weight loss with applied load after wear test for $\mathbf{4 0}$ minutes for two groups of samples; austempering time: 120 minutes 


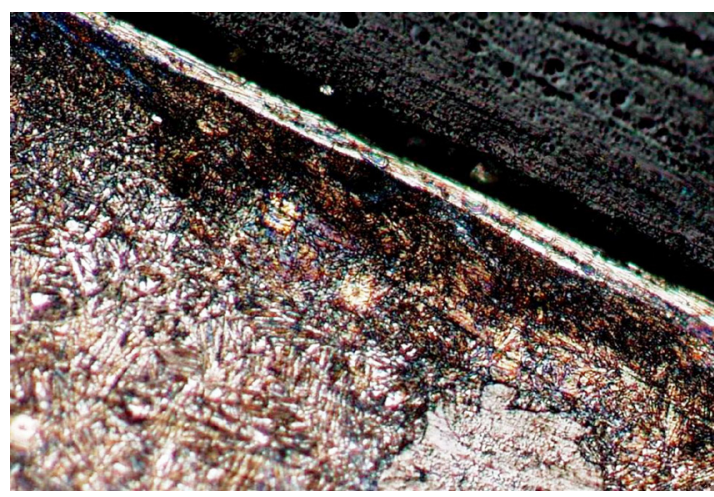

Fig. 8: Microstructure of plastically deformed layer below surface of specimen austempered at $320^{\circ} \mathrm{C}$ for 120 minutes (Group II) after wear test for one hour under the load of $100 \mathrm{~N}$

below the surface.

The dark zone in this area is the work hardening region, which is over-etched. Figure 9 indicates the deformation of a graphite nodule due to applied load during wear test. The graphite nodule with low strength can not resist against the elastic strain caused
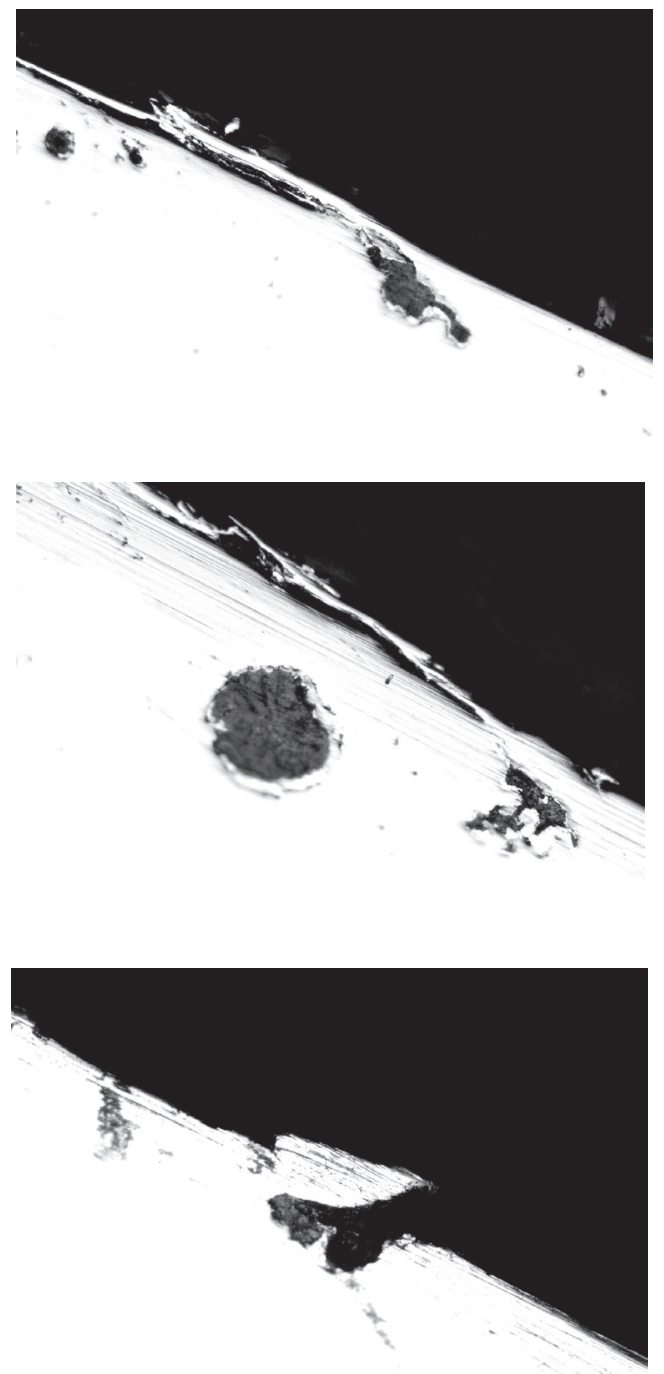

Fig. 9: Micrograph from cross-section of worn surface: (a) deformation (tongue-like) of graphite nodule, (b) fracture time and (c) sapling time by wear stresses, which results in graphite pitting on worn surface. Consequently, a tongue-like matrix extension is formed above the graphite side of the matrix boundary. The figures show that the matrix over the graphite channel is heavily deformed and fractured as a result of stretching deformation. The depletion of graphite out of the channel and increasing the load would accelerate fracture of material over the channel and therefore, the wear of material increases. It is reported that the toughness of the matrix and nodule count play an important role on the fracture of material over the channel ${ }^{[3]}$. Nili et al. ${ }^{[1]}$ have reported that the delaminated region over graphites is one of the sources of wear debris. The appearance of the wear debris is shown in Fig. 10. In other studies ${ }^{[5,6]}$, it is reported that these are fine particles of $\mathrm{Fe}_{2} \mathrm{O}_{3}, \mathrm{FeO}$ and $\mathrm{Fe}_{3} \mathrm{O}_{4}$ that are detached from the worn surface regardless of sliding velocities and applied loads. Scratches and scars on the wear surface are thought to be caused by the oxide debris that retained between the rubbing surface (Fig. 5).

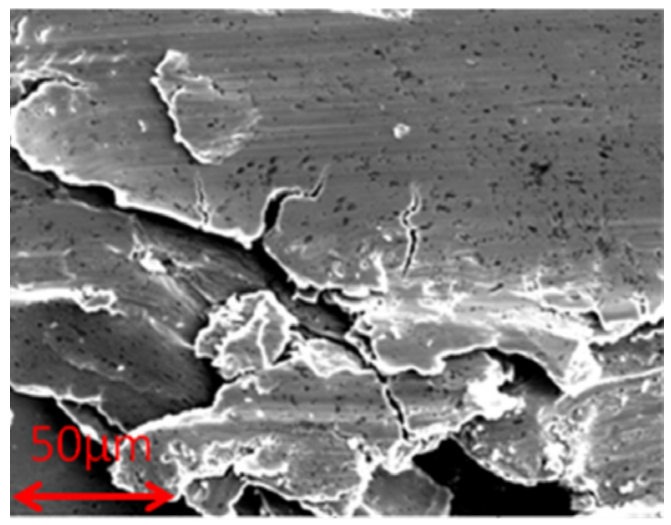

Fig. 10: SEM micrograph of wear debris formed during test

In agreement with previous research ${ }^{[2]}$, wear of ADI can be considered as a fatigue phenomenon that consists of the nucleation of cracks below or on the surface and growth of these cracks and finally the breaking of the metal particles. In sliding wear, cracks grow parallel to the surface under different loads until they reach a length for which the complex state of stress at the crack tip changes its path toward the surface and final breaking of the metal particles follows immediately. Prado et al ${ }^{[7]}$ analysed wear of ADI by the well-known Paris equation:

$$
\frac{d a}{d N}=c(\Delta k)^{m}
$$

where $\frac{d a}{d N}$ represents the crack growths rate and $c$ and $m$ are material constants. The $\Delta k$ term corresponds to the stress intensity range, which is the difference between the maximum and minimum stress intensity factors, $K_{\max }$ and $K_{\min }$, as :

$$
\Delta k=K_{\max }-K_{\min }
$$

On the other hand, the intensity factor $\mathrm{K}$ itself has a close dependency with stress $(\sigma)$ which cause a crack near the specimen surface. During a wear cycle, the applied stress on each point on the surface of the sample varies between $\sigma$ (normal applied load stress) and zero. Depending on whether or not 
they are under contact, the value of $K_{\min }$ is zero and the stress intensity range, $\Delta k$, coincides with $K_{\max }$ resulting in a function of applied stress. The extension of the crack growth stage depends on the value of $K_{\mathrm{IC}}$. The variation of the critical stress intensity factor, $K_{\mathrm{IC}}$, with retained austenite, resulting from different austempering temperatures in ADI has been studied by Arzanbal ${ }^{[15]}$.

As discussed earlier, the wear behaviour in a low applied load of $50 \mathrm{~N}$ for different heat treated specimens were the same. It is concluded that because of low stress for all specimens $K_{\max }<<$ $K_{\mathrm{IC}}$, so that wear behaviour under a load of $50 \mathrm{~N}$ is independent of austempering temperature. Even specimens with lower volumes of high carbon austenite (e.g. austempered at $270{ }^{\circ} \mathrm{C}$ ) show a suitable resistance to the stresses, which is created by sliding.

When applied load increases, $K_{\max }$ increases also, therefore, on the surface of specimens austempered at $270{ }^{\circ} \mathrm{C}$, because of a low $K_{\mathrm{IC}}$, unstable propagation of cracks takes place sooner than that of the other specimens (austempered at 320 and 370 $\left.{ }^{\circ} \mathrm{C}\right)$. At higher austempering temperatures, results show that specimens have higher wear resistance at an applied load of $150 \mathrm{~N}$. Therefore, it is expected that by the increase of $K_{\mathrm{IC}}$ at austempering temperature of $370{ }^{\circ} \mathrm{C}$, specimens can tolerate higher stresses, which is created by sliding. According to equation 3 , a high number of cycles requires reaching the critical crack length. The influence of $K_{\mathrm{IC}}$ value is important, when $K_{\max }$ is always smaller than $K_{\mathrm{IC}}$. In this case, material characteristics determine the dry wear behaviour of ADI. Therefore, in high applied loads, high austempering temperatures are more useful and effective in improving the wear behaviour of ADI.

\section{Conclusions}

By studying the segregation behaviour of austempered ductile irons with compositions of $\mathrm{Fe}-3.56 \mathrm{C}-2.67 \mathrm{Si}-0.25 \mathrm{Mo}-0.5 \mathrm{Cu}$ and $\mathrm{Ni}$ contents of 0.8 and 1.5 in wt.\%, the following conclusions can be drawn:

(1) The dry sliding wear resistance is independent of the austempering temperature for low applied loads, but it shows a strong dependence on austempering temperature for high applied loads.

(2) With increasing Ni content, wear resistance at high austempering temperatures and high applied loads increases.

(3) Strain-induced martensite transformation and work hardening of austenite in an ausferrite structure are responsible for the good wear resistance of ADI under high applied loads.

(4) The results of this study suggest that subsurface fatigue takes places during dry sliding wear of ADI and graphite spheroids lying close to the surface deform plastically from early stages of wear and act as crack nucleation sites.

\section{References}

[1] Ahmadabadi M N, Ghasemi H M, and Osia M. Effects of successive austempering on the tribological behaviour of ductile cast iron. Wear, 1999, 231(2): 293-300.

[2] Prado J M, Pujol A, Cullell J,et al. Dry sliding wear of austempered ductile iron. Materials Science and Technology, 1995, 11(3): 294 298.

[3] Liu Ping, Bahadur S, and Verhoeven J D. Friction and wear behaviour of high silicon bainitic structures in austempered cast iron and steel. Wear, 1990, 138(1-2): 269-284.

[4] Gundlach R, and Janowak J. Process overview/wear and abrasion testing. In: The Proceedings of the 2nd International Conference on Austempered Ductile Iron: Your Means to Improve Performance, Productivity and Cost, 1986: 23-30.

[5] Fordyce E P, and Allen C. The dry sliding wear behaviour of an austempered spheroidal cast iron. Wear, 1990, 135(2): 265-278.

[6] Lu Guang-Xi, and Zhang Hong. Sliding wear characteristics of austempered ductile iron with and without laser hardening. Wear, 1990, 138(1-2): 1-12

[7] Kovacs Sr B V. Austempered ductile iron: fact and fiction. Mod. Cast., 1990, 80(3): 38-41.

[8] ASTM A897 / A897M-15, Standard Specification for Austempered Ductile Iron Castings, ASTM International, West Conshohocken, PA, 2015,www.astm.org

[9] Yazdan, S, and Elliott R. Influence of molybdenum on austempering behaviour of ductile iron, Part 1-Austempering kinetics and mechanical properties of ductile iron containing $0.13 \% \mathrm{Mo}$. Materials Science and Technology, 1999, 15(5): 531-540.

[10] Yazdani S, and Elliott R. Influence of molybdenum on austempering behaviour of ductile iron, Part 2-Influence of austenitising temperature on austempering kinetics, mechanical properties, and hardenability of ductile iron containing $0.13 \%$ Mo. Materials Science and Technology, 1999, 15(5): 541-546.

[11] Yazdani S, and Elliott R. Influence of molybdenum on austempering behaviour of ductile iron, Part 3-Austempering kinetics, mechanical properties, and hardenability of ductile iron containing 0.25\% Mo. Materials Science and Technology, 1999, 15(8): 885895.

[12] Yazdani S, and Elliott R. Influence of molybdenum on austempering behaviour of ductile iron Part 4 - Austempering behaviour of ductile iron containing $0.45 \%$ Mo. Materials Science and Technology, 1999, 15(8): 896-902.

[13] Yazdani S, and Ardestani M. Effect of sub-zero cooling on microstructure and mechanical properties of a low alloyed austempered ductile iron. China Foundry, 2007, 4(2):120-123

[14] Rahimi M A, and Yazdani S. Influence of austempering heat treatment parameters and $\mathrm{Ni}$ content on the mechanical properties of austempered ductile iron. In: The Proceedings of the First National Conference on Austempered Ductile Iron, Iran Tractor Manufacturing Company, Tabriz, Iran Apr. 2008.

[15] Aranzabal J, Gutierrez I, JM Rodriguezibabe J M, et al. Influence of the amount and morphology of retained austenite on the mechanical properties of an austempered ductile iron. Metallurgical and Materials Transactions A, 1997, 28(5): 1143-1156.

[16] Bosnjak B, Radulovic B, Kiro P T, et al. Microstructural and Mechanical Characteristics of Low Alloyed Ni-Mo-Cu Austempered Ductile Iron. ISIJ international, 2000, 40(12): 1246-1252.

[17] Voigt R C. Austempered Ductile Iron--Processing and Properties. Cast Met., 1989, 2(2): 71-93. 